\title{
Alternatives for examining daughter performance of progeny-test bulls between official evaluations
}

\author{
H. D. Norman, ${ }^{* 1}$ J. R. Wright, ${ }^{*}$ and K. A. Weigel† \\ *Animal Improvement Programs Laboratory, Agricultural Research Service, USDA, Beltsville, MD 20705-2350 \\ †Department of Dairy Science, University of Wisconsin-Madison, Madison 53706
}

\begin{abstract}
In August 2007, the USDA changed from calculating official genetic evaluations quarterly to triannually in conjunction with the schedule change for international evaluations. To offset part of the delay in providing genetic information because of the reduced frequency of official evaluations, industry cooperators requested that interim evaluations be initiated for progenytest (PT) bulls based on first-lactation records from PT daughters and their contemporaries that calved recently in cooperator herds. Alternatives for interim evaluations were studied to determine which would characterize genetic merit of PT bulls most accurately. Four alternative Holstein data sources were examined based on maximum data interval (most recent 12 or 18 mo of first calvings) and minimum number of PT daughters in herd $(\geq 1$ or $\geq 5)$. The highest correlation between August 2006 interim and official evaluations for milk yield was 0.980 for interim evaluations based on the most recent 18 mo of first calvings from cooperator herds with $\geq 1 \mathrm{PT}$ daughter. That high correlation confirmed that interim evaluations based on limited data could provide genetic estimates of value between official evaluations. With the support of the Council on Dairy Cattle Breeding, the USDA initiated 3 interim evaluations each year with release limited to PT bulls with $\geq 10$ daughters and an increase in reliability since the most recent official evaluation.
\end{abstract}

Key words: interim evaluation, progeny test, daughter performance

\section{INTRODUCTION}

Obtaining access to genetic information quickly is essential if dairy semen and embryo suppliers are to remain competitive in the aggressive international marketing environment. Furthermore, improvements in the efficiency of progeny-test (PT) programs and advancements in computer hardware and software have

Received September 17, 2008.

Accepted December 11, 2008.

${ }^{1}$ Corresponding author: duane.norman@ars.usda.gov the potential to enhance genetic progress via shorter generation intervals. However, that potential can only be realized if genetic information is provided to the industry in a timely manner. The calculation of sire evaluations that included lactation records that were still in progress (Powell et al., 1975) was extremely effective in increasing the rate of genetic improvement because genetic evaluations could be released about 10 mo earlier. For the same reason, efforts are currently underway to determine whether SNP can help to identify bulls of superior genetic merit at a younger age than can be achieved through conventional progeny testing (Meuwissen et al., 2001; VanRaden et al., 2009). The time required to process domestic US genetic evaluations was reduced substantially over the last decade (from 2 mo to less than a week), even while evaluations for more traits were added (Norman and Hubbard, 1998). When the USDA changed from 2 to 4 genetic evaluations per year in 1997, each week of earlier information delivery was estimated to be worth $\$ 5$ million to producers (Norman and Hubbard, 1998). That estimate was derived from a trend in bull breeding values from 1995 to 1996 of $110 \mathrm{~kg}$ of milk per year (Animal Improvement Programs Laboratory, 2008) and a mean milk price from January through March 1997 of $\$ 0.2712 / \mathrm{kg}$ (Economic Research Service, 1997).

The decision of the Steering Committee of Interbull (Uppsala, Sweden) to reduce the number of official evaluations per year from 4 to 3 (Interbull, 2006) delays access to new genetic information by $15 \mathrm{~d}$. In addition, the current Interbull schedule for combining national evaluations into an international evaluation (Interbull, 2006) adds an additional $14 \mathrm{~d}$ to the processing intervals for April and August evaluations and an additional $35 \mathrm{~d}$ to the interval for January evaluations. Without interim evaluations or some other modification, the revised evaluation schedule would delay US producers from obtaining and using genetic information by $36 \mathrm{~d}$ on average. The long delays are a concern because they cost producers approximately $\$ 11$ million per year because of slowed genetic improvement, which also slows the rate at which benefits from increased production efficiency are transferred from producer to consumers. 
Interim sire evaluations have not been available routinely in the United States, but in nearly all other major dairy countries, the industry receives routine updates on the performance of bull daughters, sometimes as often as every $3 \mathrm{wk}$ (Interbull, 2008). If interim evaluations are accurate and provided in a timely fashion, they will allow the US AI industry to bank semen for bulls of potentially high genetic merit that are likely to have semen released for widespread marketing after the next official sire evaluation. As a result, PT bulls will return to active service sooner because semen will be adequately banked to meet producer demand.

The objective of this study was to investigate the feasibility of obtaining interim evaluations for PT bulls based exclusively on records of daughters and daughter contemporaries with recent first calvings in cooperator herds. Specifically, can first-parity milk, fat, and protein records from a small subset of herds provide predictions of subsequent official genetic evaluations for PT bulls that are accurate enough to allow AI organizations to bank large volumes of semen for new bulls with favorable prospects of being actively marketed after the next official sire evaluation? A secondary objective was to assess if the same interim evaluation had any value for older bulls that were already being marketed based on previously released official sire evaluations.

\section{MATERIALS AND METHODS}

Two criteria were considered in selecting data for interim sire evaluations in a $2 \times 2$ factorial design: maximum data interval based on date of first calving and minimum number of PT daughters per cooperator herd. First-parity milk records from PT daughters and their contemporaries that had first calved in either the most recent 12 or 18 mo were selected from cooperator herds that had a minimum of either 1 or $5 \mathrm{PT}$ daughters per herd in the designated time period. Interim evaluations were computed from each of the 4 data sets and compared with previous (May 2006) and concurrent (August 2006) official USDA-DHIA sire evaluations.

To determine the effectiveness of the alternative interval choices for including data in interim evaluations, the cutoff date for data inclusion in the interim evaluation was chosen to be the same as for August 2006 official evaluations, and the interim evaluations are referred to as August 2006 interim evaluations. That approach revealed information about the impact of the selected data and eliminated any distractions from unnecessary independent sampling. The assumption was made that the same conclusions would be drawn if evaluations at different times during the year were examined (e.g., 2 mo earlier or later, a likely schedule for interim evaluations if official evaluations were released every $4 \mathrm{mo}$ ).
Bulls were considered to be PT bulls if they had a bull status code of $\mathrm{P}$ (multiherd sampled) in their USDA bull evaluation record (data exchange format 38). Daughters of Holstein PT bulls from August 2006 official evaluations were selected if the herds had $\geq 1$ or $\geq 5$ first-parity PT daughters that first calved during the 12 or 18 mo before the data cutoff date for the official evaluation. Only first-parity milk records of PT daughters and their contemporaries from eligible herds during the designated calving period were included.

Current USDA-DHIA animal model methodology (Wiggans and VanRaden, 1989) was used to calculate interim evaluations. All animals included in the $\mathrm{Au}-$ gust 2006 interim evaluations were also included in the August 2006 official USDA-DHIA evaluation but not the reverse. A requirement that in-progress records be $\geq 40 \mathrm{~d}$ long for official evaluations was also imposed for interim evaluations and excluded those daughters with $<40 \mathrm{~d}$ in the available record at the cutoff dates for each of the evaluations used in the study.

The primary difference between official and interim evaluations was the records selected for inclusion. In addition to restricting data interval and herds, interim evaluations also included only first-parity records, whereas official evaluations are based on lactation records from the first 5 parities. However, for most PT bulls, first-parity records are the only records available for their official evaluations. Setting the genetic base population for interim evaluations to be cows that were born in 2000 was not feasible because those cows were not included in interim evaluations; therefore, a 2000 base was approximated by setting the mean PTA for bulls with $\geq 10$ daughters in the August 2006 interim evaluation to be the same as their mean in the May 2006 official evaluation.

Correlations were calculated among August 2006 interim evaluations from the 4 data sets and May and August 2006 official evaluations to compare the alternative interim evaluations with official evaluations based on all data available near the same time. Correlations were calculated separately for PT bulls and non-PT bulls with records from $\geq 10$ daughters in their interim evaluations. Non-PT bulls were AI bulls that no longer were coded as PT and had sired contemporaries of PT bull daughters. For bulls without a May 2006 official evaluation, mean of sire and dam PTA milk (i.e., May 2006 parent average) was used.

Relationships between evaluations that were based on different numbers of added daughters were investigated for both PT and non-PT bulls that were sires of PT daughter contemporaries. To examine how the amount of added information affected accuracy of the interim evaluation, bulls were grouped into deciles based on the difference in daughter numbers between May 2006 
Table 1. Numbers of Holstein bulls, ${ }^{1}$ daughters per bull, and correlations among PTA milk from August 2006 interim evaluations and May and August 2006 official USDA-DHIA evaluations by bull AI status, first-parity data included in the interim evaluation, and number of progeny-test (PT) daughters in the herd

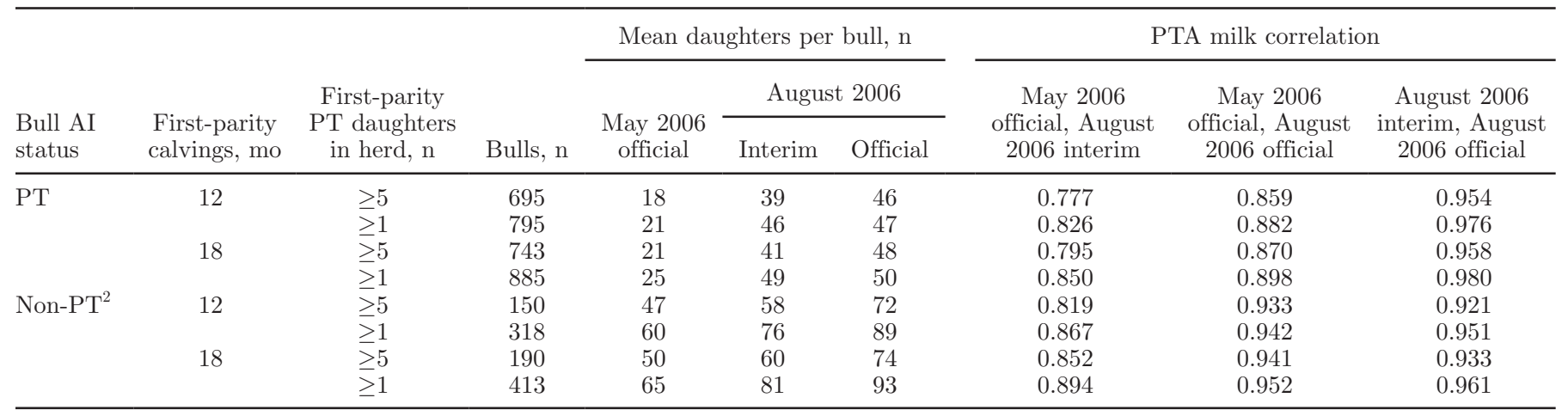

${ }^{1}$ Bulls with $\geq 10$ daughters for the August 2006 interim evaluation based on the data cutoff date for the August 2006 official evaluation and an increase in reliability since the May 2006 official evaluation.

${ }^{2}$ Artificial insemination bulls that no longer were coded as PT and had sired contemporaries of PT bull daughters.

official and August 2006 interim evaluations. Bulls with predominantly new daughters were in the upper deciles, and bulls with few new daughters were in the lower deciles.

Distribution of differences between interim and official evaluations was examined to provide information about future expected variation from an interim evaluation procedure. Correlations also were calculated with official evaluations 2 yr later (August 2008) to reveal how effective all evaluations were in predicting genetic merit after daughters were added over an extended time.

\section{RESULTS AND DISCUSSION}

Table 1 shows numbers of bulls and mean daughters per bull for Holstein bulls with a reliability increase between the May 2006 official evaluation and the interim evaluation. Some PT bulls had only parent averages in May 2006: 323 (46\%) for interim evaluations based on herds with $\geq 5 \mathrm{PT}$ daughters and the most recent 12 mo of daughter first calvings, 345 (43\%) for $\geq 1 \mathrm{PT}$ daughter per herd and a first-calving period of $12 \mathrm{mo}$, $326(44 \%)$ for $\geq 5$ PT daughters per herd and a firstcalving period of $18 \mathrm{mo}$, and $348(39 \%)$ for $\geq 1 \mathrm{PT}$ daughter per herd and a first-calving period of 18 mo. As expected, more bulls had interim evaluations (i.e., $\geq 10$ daughters) when those evaluations were based on the most recent 18 rather than 12 mo of daughter first calvings regardless of bull PT status. Mean daughters per bull also increased as the calving period was lengthened. Numbers of bulls with interim evaluations and mean daughters per bull decreased as the number of PT daughters per herd required for an evaluation increased. The increase in number of bulls evaluated based on herds with $\geq 1$ PT daughter compared with herds with $\geq 5$ PT daughters was about twice as great as the increase from lengthening the first-calving period from 12 to 18 mo. The corresponding gain difference for number of daughters per bull was even greater: about 3 times more for PT bulls and over 4 times more for non-PT bulls.

Correlations between August 2006 interim and official evaluations (Table 1) were generally high (0.954 to 0.980 for PT bulls). Correlations between May and August 2006 official evaluations for the same bulls were considerably lower (0.859 to 0.898). Regardless of the evaluations compared, correlations for PT bulls were highest (0.850 to 0.980) when the evaluation was based on all herds with PT daughters and a firstcalving period of $18 \mathrm{mo}$ and lowest (0.777 to 0.954 ) when the evaluation was based only on herds with $\geq 5$ PT daughters and a first-calving period of 12 mo. The higher correlations for herds with fewer PT daughters and longer calving periods can be attributed to the greater number of total daughters per bull for interim evaluations, which provides more information in common between interim and official evaluations.

For evaluations of PT bulls based on a first-calving period of $18 \mathrm{mo}$ and herds with $\geq 1 \mathrm{PT}$ daughter, correlations were 0.980 between August 2006 interim and official evaluations and 0.898 between May and August 2006 official evaluations. Corresponding correlations for evaluations of PT bulls were 0.976 and 0.882 based on a 12 -mo first-calving period and herds with $\geq 1$ PT daughter and 0.958 and 0.870 based on an 18-mo first-calving period and herds with $\geq 5 \mathrm{PT}$ daughters. Although the correlation between August 2006 interim and official evaluations was highest for evaluations based on a first-calving period of $18 \mathrm{mo}$ 
and all herds with PT daughters, it was only slightly higher than that from 12 mo of data from all PT herds. The primary benefit from including data from the most recent 18 mo of first calvings rather than 12 mo was that accurate updates were provided for an additional 90 PT bulls.

Few of the interim evaluations were helpful for nonPT bulls. Correlations between interim and official evaluations for non-PT bulls that were sires of PT daughter contemporaries were substantially lower (by 0.098 to 0.132 ; not shown) than corresponding correlations between May and August 2006 official evaluations. The lower correlations for non-PT than for PT bulls likely were caused by the limited time period for data and herd restrictions for interim evaluations compared with official evaluations. Only 8 to $15 \%$ of total records used for August 2006 official evaluations were included in interim evaluations because of the restriction for only first-parity records of PT daughters and their contemporaries. The only daughters of non-PT bulls that had first-parity records included in interim evaluations were those that were contemporaries of PT daughters. Often a large percentage of daughters of non-PT bulls had calved during earlier years or were in herds that did not participate in progeny testing. Even when interim evaluations were examined for non-PT bulls that increased in reliability (Table 1), correlations between interim and August 2006 official evaluations (0.921 to 0.961) were nearly the same as between May and August 2006 official evaluations (0.933 to 0.952). Thus, no advantage was found for releasing interim evaluations based on recent first-parity daughter records for non-PT bulls.

For the interim evaluation with the highest correlation with August 2006 official evaluations (first-parity records from the most recent 18 mo of calving from all herds with PT daughters), $74 \%$ of PT bulls had more daughters for the August 2006 interim evaluation than for the May 2006 official evaluation (Table 2). The PT bulls with few new daughters (primarily the lowest 3 deciles) likely were older bulls that did not have their AI status changed to inactive despite the fact that their semen was no longer being marketed; those bulls had more daughters for the May 2006 official evaluation than for the interim evaluation. Because the interim evaluation was based on a subset of the data for the August 2006 official evaluation, no bull could have more daughters for his interim evaluation than for his August 2006 official evaluation.

For PT bulls, correlations were higher between the interim and official August 2006 evaluations (Table 2 ) when bulls had a higher percentage of daughters in common. Bulls with the most daughters added (decile 10) had the highest correlation between interim and official August 2006 evaluations (0.987), whereas the correlation between May and August 2006 official evaluations was considerably lower (0.830). If interim information had not been available, the best alternative would have been to rely on parent averages from the previous evaluation, which were substantially less accurate. For PT bulls in decile 1 (fewer daughters for the August 2006 interim evaluation than for the May 2006 official evaluation), the correlation between August 2006 interim and official evaluations (0.922) was much lower than the correlation between May and August 2006 official evaluations (0.997). The mean reliability for August 2006 interim evaluations (not shown) for bulls in decile 1 also was considerably lower than their May 2006 official reliability, a reflection of the lower mean number of daughters for the interim evaluation (44) compared with the May 2006 official evaluation (136). If the status for those bulls had been changed from multiherd-sampled to inactive, they would not have been included in the PT data set and, therefore, would not have had a negative impact on the mean accuracy of interim evaluations for PT bulls.

Of the 1,274 PT bulls, 945 had more daughters for the August 2006 interim evaluation than for the May 2006 official evaluation (Table 2). Those bulls had a correlation of 0.978 between the interim and official August 2006 evaluations but only a correlation of 0.903 between May and August 2006 official evaluations. The 329 PT bulls with fewer or the same number of daughters had a higher correlation between May and August 2006 official evaluations (0.994) than between August 2006 interim and official evaluations (0.931), which indicated that breeding decisions based on their interim evaluations would be counterproductive.

For non-PT bulls, $85 \%$ had fewer or the same number of daughters for their interim evaluations than for May 2006 official evaluations (Table 2). Correlations for those bulls were nearly always lower between August 2006 interim and official evaluations (0.868) than between May and August 2006 official evaluations (0.994). For the $15 \%$ of non-PT bulls with more daughters for interim evaluations than for official May 2006 evaluations, corresponding correlations were nearly the same (0.955 and 0.954 , respectively). Interim evaluations without improved accuracy (as indicated by correlations between evaluations) over previous official evaluations would be of no benefit to dairy breeders.

Table 3 shows the actual differences in PTA milk between August 2006 interim evaluations based on first calvings during the most recent 18 mo and August 2006 official evaluations by decile. Mean absolute differences in PTA milk between interim and official August 2006 evaluations were $67 \mathrm{~kg}$ for herds with $\geq 1 \mathrm{PT}$ daughter and $85 \mathrm{~kg}$ for herds with $\geq 5$ PT daughters. Most (80\%) 
Table 2. Numbers of Holstein bulls and daughters per bull and correlations among PTA milk from August 2006 inte
evaluations by decile for difference in daughter numbers between May 2006 official and August 2006 interim evaluations

\begin{tabular}{|c|c|c|c|c|c|c|c|c|}
\hline \multirow[b]{3}{*}{$\begin{array}{l}\text { Bull AI } \\
\text { status }\end{array}$} & \multirow[b]{3}{*}{$\begin{array}{l}\text { Daughter difference }{ }^{2} \\
\text { decile (range, } \mathrm{n})\end{array}$} & \multirow[b]{3}{*}{ Bulls, n } & \multicolumn{3}{|c|}{ Mean daughters per bull, $\mathrm{n}$} & \multicolumn{3}{|c|}{ PTA milk correlation } \\
\hline & & & \multirow[b]{2}{*}{$\begin{array}{c}\text { May } 2006 \\
\text { official }\end{array}$} & \multicolumn{2}{|c|}{ August 2006} & \multirow[b]{2}{*}{$\begin{array}{l}\text { May } 2006 \text { official, } \\
\text { August } 2006 \text { interim }\end{array}$} & \multirow[b]{2}{*}{$\begin{array}{l}\text { May } 2006 \text { official, } \\
\text { August } 2006 \text { official }\end{array}$} & \multirow[b]{2}{*}{$\begin{array}{l}\text { August } 2006 \text { interim, } \\
\text { August } 2006 \text { official }\end{array}$} \\
\hline & & & & Interim & Official & & & \\
\hline \multirow[t]{13}{*}{$\mathrm{PT}^{3}$} & $1(-39$ to -508$)$ & 127 & 136 & 44 & 140 & 0.917 & 0.997 & 0.922 \\
\hline & $2(-6$ to -38$)$ & 128 & 59 & 41 & 61 & 0.914 & 0.993 & 0.913 \\
\hline & $3(-5$ to 2$)$ & 126 & 50 & 49 & 52 & 0.963 & 0.992 & 0.973 \\
\hline & $4(3$ to 9$)$ & 140 & 49 & 55 & 56 & 0.951 & 0.984 & 0.975 \\
\hline & $5(10$ to 13$)$ & 113 & 22 & 34 & 34 & 0.895 & 0.942 & 0.971 \\
\hline & $6(14$ to 18$)$ & 141 & 24 & 39 & 40 & 0.842 & 0.905 & 0.971 \\
\hline & $7(19$ to 23$)$ & 113 & 25 & 46 & 47 & 0.837 & 0.899 & 0.969 \\
\hline & $8(24$ to 30$)$ & 139 & 20 & 47 & 48 & 0.824 & 0.860 & 0.986 \\
\hline & $9(31$ to 38$)$ & 115 & 17 & 51 & 52 & 0.767 & 0.826 & 0.984 \\
\hline & $10(39$ to 132$)$ & 132 & 20 & 71 & 71 & 0.776 & 0.830 & 0.987 \\
\hline & All bulls & 1,274 & 42 & 60 & 60 & 0.871 & 0.933 & 0.963 \\
\hline & Bulls with more daughters & 945 & 27 & 51 & 51 & 0.853 & 0.903 & 0.978 \\
\hline & $\begin{array}{l}\text { Bulls with fewer or same } \\
\text { number of daughters }\end{array}$ & 329 & 42 & 89 & 89 & 0.926 & 0.994 & 0.931 \\
\hline \multirow[t]{13}{*}{ Non-PT ${ }^{4}$} & $1(-1,892$ to $-81,114)$ & 293 & 9,990 & 782 & 10,193 & 0.887 & 1.000 & 0.887 \\
\hline & $2(-392$ to $-1,888)$ & 294 & 1,270 & 347 & 1,346 & 0.822 & 0.999 & 0.823 \\
\hline & $3(-134$ to -389$)$ & 294 & 387 & 162 & 425 & 0.792 & 0.998 & 0.797 \\
\hline & $4(-81$ to -133$)$ & 296 & 168 & 66 & 182 & 0.785 & 0.994 & 0.798 \\
\hline & $5(-56$ to -80$)$ & 295 & 130 & 62 & 147 & 0.787 & 0.993 & 0.802 \\
\hline & $6(-28$ to -55$)$ & 295 & 105 & 63 & 118 & 0.868 & 0.992 & 0.872 \\
\hline & $7(-11$ to -27$)$ & 298 & 98 & 80 & 109 & 0.920 & 0.991 & 0.925 \\
\hline & $8(-4$ to -10$)$ & 263 & 79 & 72 & 88 & 0.955 & 0.989 & 0.964 \\
\hline & $9(-3$ to 7$)$ & 326 & 66 & 67 & 76 & 0.941 & 0.978 & 0.969 \\
\hline & $10(8$ to 509$)$ & 284 & 124 & 156 & 201 & 0.865 & 0.943 & 0.945 \\
\hline & All bulls & 2,938 & 1,239 & 185 & 1,286 & 0.865 & 0.989 & 0.880 \\
\hline & Bulls with more daughters & 443 & 101 & 124 & 155 & 0.887 & 0.954 & 0.955 \\
\hline & $\begin{array}{l}\text { Bulls with fewer or same } \\
\text { number of daughters }\end{array}$ & 2,495 & 1,441 & 196 & 1,486 & 0.861 & 0.994 & 0.868 \\
\hline
\end{tabular}

${ }^{1}$ Bulls with $\geq 10$ daughters for the August 2006 interim evaluation based on first-parity records from calvings during the most recent 18 mo in herds with $\geq 1$ progeny-test daugher

${ }^{2}$ Number of daughters for August 2006 interim evaluation minus number of daughters for May 2006 official evaluation.

${ }^{3}$ Progeny test.

${ }^{4}$ Artificial insemination bulls that no longer were coded as PT and had sired contemporaries of PT bull daughters. 
Table 3. Mean PTA milk differences between August 2006 interim $^{1}$ and August 2006 official USDA-DHIA evaluations for Holstein progeny-test (PT) bulls with $>10$ daughters for the interim evaluation and mean numbers of daughters by number of PT daughters in the herd and decile for PTA milk difference

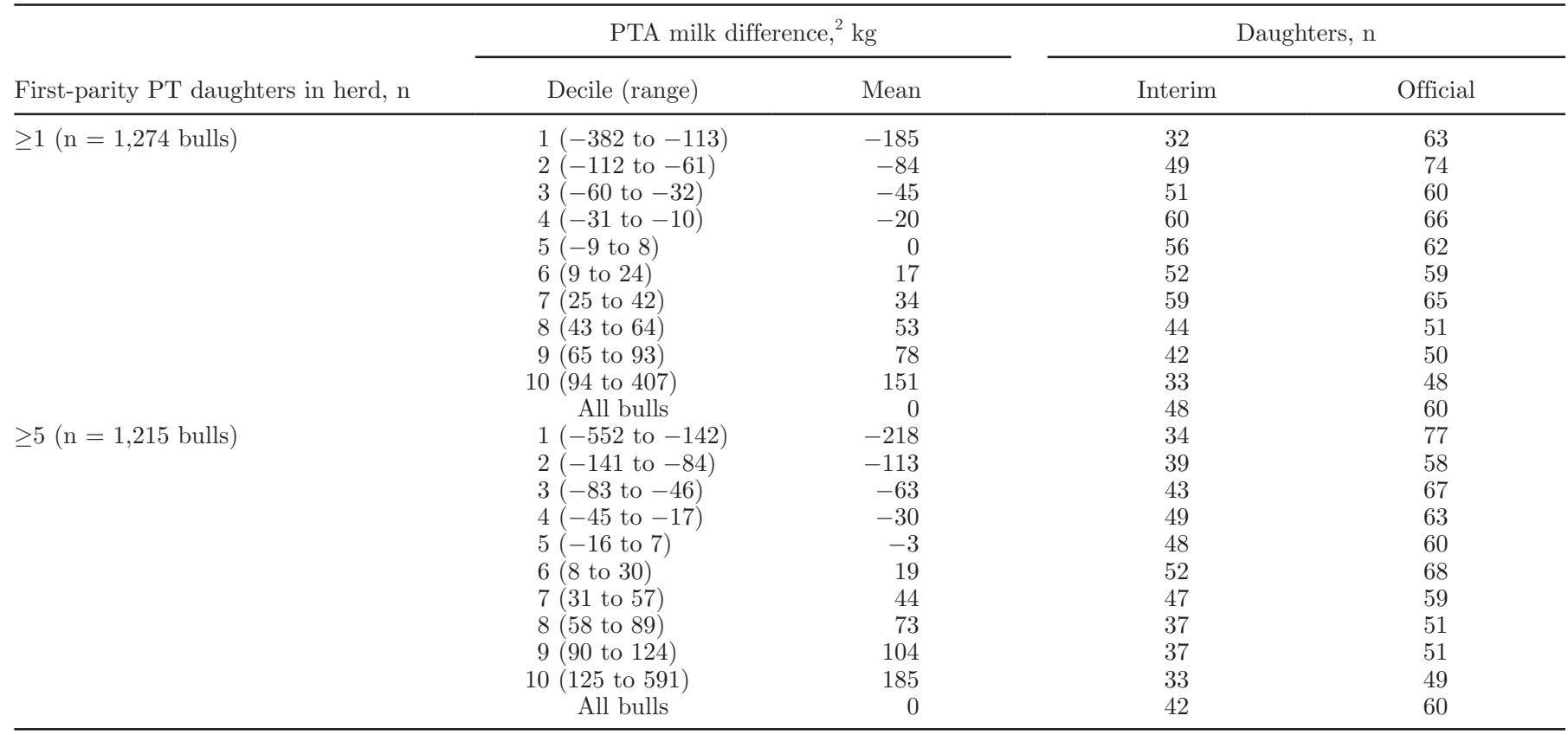

${ }^{1}$ Based on first-parity records from calvings during the most recent 18 mo.

${ }^{2}$ Predicted transmitting ability milk from August 2006 official evaluation minus PTA milk from August 2006 interim evaluation.

PT bulls had PTA milk differences between -112 and $93 \mathrm{~kg}$ when records were from herds with $\geq 1$ PT daughter and between -141 and $124 \mathrm{~kg}$ when records were from herds with $\geq 5$ PT daughters. Using first-lactation records from daughters in all PT herds (those with $\geq 1$ PT daughter) resulted in interim evaluations that were more similar to official evaluations than those based on daughters in herds with $\geq 5 \mathrm{PT}$ daughters, probably because of more information in common between interim and official evaluations for herds with $\geq 1 \mathrm{PT}$ daughter.

Table 4 shows correlations among the most favorable of the 4 alternative August 2006 interim evaluations (those based on first calvings during the most recent 18 mo in herds with $\geq 1 \mathrm{PT}$ daughter) and official evaluations in May 2006, August 2006, and August 2008 by bull decile based on differences in reliability between May 2006 official and August 2006 interim evaluations. For bulls with increased reliability, the correlation between August 2006 interim evaluations and August 2008 official evaluations (0.863) was higher than between May 2006 and August 2008 official evaluations (0.807), which illustrates that access to an interim evaluation 3 mo after an official evaluation was extremely valuable. August 2006 official evaluations were not much more accurate in predicting official evaluations $2 \mathrm{yr}$ later (correlation of 0.878 vs. 0.863 ) than were interim evaluations. The correlations in Table 4 provide convincing evidence that interim evaluations are effective as a proxy for official evaluations and are also more accurate predictors of performance of new daughters than other available information.

\section{CONCLUSIONS}

Interim evaluations based on first calvings during the most recent 18 mo from all $\mathrm{PT}$ cooperator herds were nearly as accurate as official evaluation for PT bulls that had new daughters. Correlations between August 2006 interim and official evaluations for those bulls ranged from 0.97 to 0.99 compared with correlations between May and August 2006 official evaluations of 0.83 to 0.98. Interim evaluations, which contain more recent data, clearly provide predictions of subsequent official evaluations for PT bulls that are accurate enough to be of benefit to AI organizations.

Older PT bulls often had fewer daughters for the interim evaluation than for the previous official evaluation, and the correlation between August 2006 interim and official evaluations for PT bulls with fewer daughters (0.931) was lower than the correlation between May and August 2006 official evaluations (0.994). 
Based on those results, the National Association of Animal Breeders (G. Doak, Columbia, MO, personal communication) now recommends that older PT bulls have their status changed from multiherd-sampled to inactive and limits the maximum age for PT bulls. A bull now may be assigned a $\mathrm{P}$ status code only for $5 \mathrm{yr}$ after his sampling date and only until the age of $7 \mathrm{yr}$.

In October 2007, the Council on Dairy Cattle Breeding approved implementation of interim evaluations in May, September, and November for PT bulls with the stipulation that the evaluations be unofficial, unpublished, and not calculated for actively marketed bulls (Council on Dairy Cattle Breeding, 2007). Because the computer time required to calculate interim evaluations is only $25 \%$ of that needed for official evaluations, they can be calculated and provided to the dairy industry within $24 \mathrm{~h}$ of data extraction. Implementation of interim sire evaluations allows more timely bull management decisions by breeding companies and the banking of large volumes of semen for bulls that are likely to have their semen released after the next official evaluation, thereby enhancing the availability of elite genetics to US dairy producers.

\section{ACKNOWLEDGMENTS}

The cooperation of the dairy records processing centers (AgriTech Analytics, Visalia, CA; AgSource Cooperative Services, Verona, WI; Dairy Records Management Systems, Raleigh, NC, and Ames, IA; and DHI Computing Services, Provo, UT) in supplying pedigree data for grade cows and lactation yield data and of the breed associations (Holstein Association USA, Brattleboro, VT, and Red and White Dairy Cattle Association, Crystal Springs, PA) in supplying pedigree data for registered cows is acknowledged. The assistance of S. M. Hubbard of the Animal Improvement Programs Laboratory (Beltsville, MD) in manuscript review is appreciated.

\section{REFERENCES}

Animal Improvement Programs Laboratory. 2008. Trend in milk BV for Holstein or Red \& White. http://aipl.arsusda.gov/eval/summary/ trend.cfm?R_Menu=HO.m\#StartBody Accessed August 4, 2008.

Council on Dairy Cattle Breeding. 2007. Minutes of meeting, October 23, 2007, Milwaukee, WI.

Economic Research Service. 1997. Livestock, Dairy, and Poultry Outlook, 04.16.1997. http://usda.mannlib.cornell.edu/usda/ers/ LDP-M//1990s/1997/LDP-M-04-16-1997.txt Accessed August 4, 2008.

Interbull. 2006. New evaluation schedule. Interbulletin, Aug. 2006. Interbull, Uppsala, Sweden.

Interbull. 2008. National GES information. http://www-interbull. slu.se/national_ges_info2/framesida-ges.htm Accessed August 7, 2008 . 
Meuwissen, T. H., B. J. Hayes, and M. E. Goddard. 2001. Prediction of total genetic value using genome-wide dense marker maps. Genetics 157:1819-1829.

Norman, H. D., and S. M. Hubbard. 1998. Enhancing genetic improvement for milk yield by reducing generation interval. AIPL Res. Rep. AWD1(11-98). Animal Improvement Programs Laboratory, ARS, USDA, Beltsville, MD.

Powell, R. L., H. D. Norman, and F. N. Dickinson. 1975. Analysis of the USDA-DHIA preliminary sire summary. J. Dairy Sci. 58:551557 .
VanRaden, P. M., C. P. Van Tassell, G. R. Wiggans, T. S. Sonstegard, R. D. Schnabel, J. F. Taylor, and F. Schenkel. 2009. Genomic data and cooperation result in faster progress. ICAR Tech. Ser. 13:341-346.

Wiggans, G. R., and P. M. VanRaden. 1989. USDA-DHIA animal model genetic evaluations. Natl. Coop. DHI Program Handb., Fact Sheet H-2. Ext. Serv., USDA, Washington, DC. 